\title{
Anna Caiozzo. «L'esprit des lieux - Quelques observations sur la topographie des merveilles terrestres dans les manuscrits enluminés de l'Orient médiéval »
}

\section{Pierre Lory}

\section{(2) OpenEdition}

\section{Journals}

Édition électronique

URL : http://journals.openedition.org/abstractairanica/48858

DOI : 10.4000/abstractairanica.48858

ISBN : 1961-960X

ISSN : 1961-960X

Éditeur :

CNRS (UMR 7528 Mondes iraniens et indiens), Éditions de l'IFRI

\section{Référence électronique}

Pierre Lory, «Anna Caiozzo. «L'esprit des lieux - Quelques observations sur la topographie des merveilles terrestres dans les manuscrits enluminés de l'Orient médiéval » », Abstracta Iranica [En ligne], Volume 40-41 | 2019, document 5, mis en ligne le 30 octobre 2019, consulté le 17 avril 2021. URL : http://journals.openedition.org/abstractairanica/48858 ; DOI : https://doi.org/10.4000/ abstractairanica.48858

Ce document a été généré automatiquement le 17 avril 2021

Tous droits réservés 
Anna Caiozzo. « L'esprit des lieux Quelques observations sur la topographie des merveilles terrestres dans les manuscrits enluminés de l'Orient médiéval »

Pierre Lory 


\section{RÉFÉRENCE}

Anna Caiozzo. «L'esprit des lieux - Quelques observations sur la topographie des merveilles terrestres dans les manuscrits enluminés de l'Orient médiéval » dans dossier spécial Merveilles, géographie et sciences naturelles au Proche-Orient médiéval, Annales islamologiques 51, 2017, p. 53-83

1 L'A. part d'un corpus d'ouvrages cosmographiques dans le registre des 'Ajä'ib almakhlūqāt. Elle retient en particulier ceux dont les manuscrits conservés contiennent des illustrations, notamment ceux d'al-Tūsî Salmānī (XII ${ }^{\mathrm{e}}$ s.) et d'al-Qazwīnī (XII ${ }^{\mathrm{e}}$ s.). Partant de là, elle passe en revue des lieux qui ont pu marquer l'imagination des médiévaux en tant que manifestation du «merveilleux». L'accent est mis sur les endroits à portée mythique, ou magique, ou simplement mystérieuse. Il peut s'agir de lieux naturels (océans et îles lointaines, montagnes étranges, fleuves et sources). Parfois, ce sont des ouvrages accomplis par des humains - monuments colossaux, ouvrages techniques ou enchantés - qui sont représentés. Enfin, des lieux de culte musulmans ou païens sont également mentionnés. A.C. souligne la portée du choix de représenter ces différents lieux, qui marquent les limites spatiales mais aussi symboliques et eschatologiques de notre monde, et l'accès éventuel à un au-delà.

\section{AUTEURS}

\section{PIERRE LORY}

EPHE, Section des Sciences Religieuses 